\title{
Action Research in EFL: Exploring Writing Pedagogy Through a Task-based Lesson Delivery
}

\author{
Zulfiqar Ahmad \\ English Language Institute (ELI), University of Jeddah, Jeddah, KSA
}

\begin{abstract}
The study attempted to move away from the more traditional Presentation, Practice, Production model of teaching to experiment with the Task Based Learning approach. Action research framework was adopted to observe a writing class with a focus on developing the paragraph level skills of the Preparatory Year EFL students. Teacher notes, peer observation report, samples of students' writing and a short student survey were used to collect the data. The results revealed that the new approach though mostly successful and effective had a few issues in regard to activity management and feedback on students' performance. The study recommends a series of similar action research initiatives to further validate the newly used teaching approach as well as introduce other pedagogic approaches which have not been practiced so far.
\end{abstract}

Index Terms - action research, EFL writing, peer observation, professional development, TBL

\section{INTRODUCTION}

Teaching as a vocation is an evolving phenomenon which if not chosen with a thorough professional intent can impede the process of professional growth. Professional intent refers to the aptitude and commitment a teacher should have to experience what Bailey and Jackson cited in Richards and Lockhart (1996) call 'change' - an essential factor of motivation for professional development. Change may be the outcome of beliefs which emerge as a result of reflection. Schon in Norton $(2009$, p.21) suggests that "we all need to reflect as we will inevitably be faced with new situations or problems for which we were not specifically trained". The idea seems to be a teacher's progression, based on reflection, from one point to the next, and so on. This progression is evident in dealing with classroom dynamics on the one hand, and pursuing professional development on the other. Schon (1983) conceptualizes the reflective practitioner as one who is systematically self-assessing as he constantly gets feedback from the external assessment process and is most times preoccupied with early identification of problems and proffering of solutions to them. One way of doing this is through action research (AR) which stimulates observation and reflection not only on one's own teaching but also as a way of bringing about change in pedagogic beliefs and practices (Richards, 1990).

\section{LITERATURE REVIEW}

\section{Action Research in EFL Pedagogy}

Following Troudi and Riley (1996), teachers' lack of involvement in syllabus design, material development and course assessment procedures may cause an inevitable gap between the pedagogic interventions and learning outcomes with a negative effect on classroom teaching and learning experience. Extending the role of the teacher to that of a researcher is likely to help identify and diagnose the context specific issues and suggest practical solutions. One such approach is the AR. Following Richards and Renandya (2002, p. 358) that "it is what teachers think and do at the classroom level that eventually determines what learners learn in the classroom", AR can be defined as a "self-reflective spiral of planning, acting, observing, reflecting, and re-planning" (McNiff \& Whitehead, 2002 p.46). In other words, AR may be understood as a realization of teacher reflection on any of the dynamics of classroom teaching. What makes AR distinct from reflective practice is that it lends concreteness and practicality to reflection which is mostly a cognitive phenomenon. AR can be conducted to figure out longstanding pedagogic issues that have impeded effective learning experience through reflection, planning, and collaboration. Research studies (e.g., Banegas, et al., 2013; Burns, 2014) have revealed that AR is potentially a highly effective resource of teacher autonomy and development as far as development through change in teaching beliefs and practices is concerned. Not only this it can also be used to identify learner needs and modify teaching accordingly. AR has a wide scope in terms of systematically dealing with pedagogical issues: A teacher can investigate any focus of interest ranging from a teaching approach to strategy or technique, identifying learning inhibitions to their remedies, evaluating the strengths and weaknesses of the course design to the instructional materials. Researchers such as Borg (2006), Burns and Westmacott (2018) and Smith et al. (2013) have also referred to the use of AR in teacher collaboration through peer observations, for instance, to resolve issues that challenge the teacher and the learner in a classroom context. AR, therefore, not only solves problems but also enhances teaching skills Banegas (2018).

Researchers have proposed different frameworks for AR. For instance, Cohen and Manion's (1985) model identifies eight areas which AR should cater for: identification of the problem, a research proposal, review of the related literature, 
formulation of hypothesis, creating a research design, deciding on the evaluation procedures, data collection and analysis, interpretation and reporting of the results. Negi (2016 p.20) has mentioned a few other frameworks as outlined in Table 1.

TABLE 1:

FRAMEWORKS FOR ACTION RESEARCH

\begin{tabular}{|c|c|c|c|c|c|}
\hline$\overline{\text { Stage }}$ & $\begin{array}{l}\text { Kemmis \& } \\
\text { McTaggart (1988) }\end{array}$ & Sagor (1992) & Calhoun (1994) & O'leary (2004) & $\begin{array}{l}\text { British Council } \\
\text { (2015) }\end{array}$ \\
\hline & Planning & Formulating Problem & $\begin{array}{l}\text { Selecting the area } \\
\text { of focus }\end{array}$ & Observing & Noticing a problem \\
\hline & Acting & Collecting data & Collecting data & Reflecting & Planning \\
\hline & Observing & Analyzing data & Organizing data & Planning & Teaching/Acting \\
\hline & Reflecting & Reporting results & $\begin{array}{l}\text { Analyzing and interpreting } \\
\text { data }\end{array}$ & Acting & Observing \\
\hline & Re-planning & Planning action & Taking action & Observing & Reflecting \\
\hline
\end{tabular}

Task Based Learning (TBL): Definition and Concept

TBL refers to an approach in language teaching where the learners are engaged in a task such as preparing a menu, visiting a doctor, etc. with the primary focus on fluency and task realization rather than on accuracy of the linguistic forms. Prabhu (1987 p.24) defines a task as "an activity which required learners to arrive at an outcome from given information through some process of thought, and which allowed teachers to control and regulate that process". Nunan (1989 p.10) uses the word 'task' instead of 'activity'. He defines a task as "a piece of classroom work which involves learners in comprehending, manipulating, producing or interacting in the target language while their attention is principally focused on meaning rather than form". According to Willis (1996 p.23) "tasks are always activities where the target language is used by the learner for a communicative purpose (goal) in order to achieve an outcome" . Comparing Presentation, Practice, Production (PPP) and TBL approaches, Harmer (2001) argues that PPP focuses on accuracy which a teacher attempts to help his students achieve through presentation of structures, drilling, practice and production, while TBL allows more control to the students as the role of the teacher is restricted to that of a facilitator. Since grammatical accuracy is of secondary importance, students' nervous anxiety is under good control and they can focus on language use for communicative purposes with higher levels of motivation. Willis and Willis (2001) observe that in TBL, tasks are different from grammar-based activities because the learners are free to use a variety of language structures to complete the tasks. This conforms to Krashen and Terrel's (1983: p. 55) view that "language is best taught when it is being used to transmit messages, not when it is explicitly taught for conscious learning". In TBL, the learners are not pre-taught the target language rather it is drawn from them with the help of a facilitator during the process of task realization (Curran and Dusap, 2000 p. 23). Hence, TBL permits the learners to use real-world language and this makes language learning an authentic experience in real-life communication.

\section{Principles of TBL}

Nunan (2004: p. 35-38) has outlined seven principles of TBL: a) Scaffolding that refers to the supporting frameworks within which the learning takes place in respect to lesson and materials; b) Task dependency which assumes that the tasks within one lesson should have a logical corollary; c) Recycling that enhances opportunities for learning and activates the 'organic' learning principle; d) Active learning which occurs when language is used effectively; e) Integration which entails that the learners should find clear links among language forms, communicative function, and semantic meaning; f) Reproduction to creation which states that learners should be motivated to progress from reproductive to creative language use; g) Reflection that expects learners to be allowed to reflect on the learning outcomes as well as their performance.

\section{TBL Framework}

A typical TBL framework is based on pre-task, the task, planning, report, analysis and practice stages (Willis, 1996). In the Pre-task stage, the teacher introduces the task and instructs the students what to do at different stages. He can also use pre-task lead-in to activate the schemata of the students with the help of, for example, pictures and other brainstorming strategies. Next, the students work in pairs or groups and use and share the language they already know. The teacher acts as facilitator and motivates them. In the planning stage a short oral or written report is prepared for presentation before the class. The students practice, with teacher's advice if needed, what they are going to say in their groups. This is followed by a presentation by the students where they present or read the written report. The teacher chooses the order of when students will present their reports and may give the students some quick feedback on the content. The analysis stage focuses on specific language features from the task which are picked up and discussed. Feedback on the learners' performance at the reporting stage may also be appropriate at this point. The final stage practice is based on the needs analysis done by the teacher during the task realization stages.

\section{Strengths of TBL}

Unlike the PPP approach, in TBL the students use the language they know. When they work in groups they share their store of language and are exposed to new language. They use personalized and real-world language, and thereby create a natural context for learning. With TBL, the students will be exposed to a whole range of lexical phrases, collocations and patterns as well as language forms (Frost, 2004). The language explored arises from the students' needs. These needs determine what will be covered in the lesson rather than a decision made by the teacher or the course book. 
TBL is, therefore, an effective communicative approach where student talk time (STT) gets priority over teacher talk time (TTT). It is interesting and motivating since it asks for collaborative work and task realization.

\section{Criticism of TBL}

One of the limitations of TBL is that it permits a limited use of the language which the learners already know. Experimenting with new words and phrases, and new structures may pose learners problems of communication and task realization. Since TBL involves group work, there is a chance that some students do not share the burden and simply rely on other group members. New learning done can be easily lost if not properly planned, or reinforced. Moreover, TBL can be a big challenge if practiced with large classes or in a limited time frame. As TBL exploits students' language and every student is expected to have a certain level of language competence, it can be challenging to successfully practice with low level classes like for example absolute beginners or false beginners.

\section{Aims and Objectives}

This AR study aimed at using Task Based Learning (TBL) as a teaching approach for Preparatory Year monolingual Arab students at the English Language Institute, (ELI), University of Jeddah, Saudi Arabia. Since PPP as a teaching framework has been quite consistently used, it was observed that despite teaching atomized language units with extensive practice in form, the students could not develop the desired language ability. However, the real motivation for experimenting with TBL was its allowance for fluency, need-based focus on form, student-centeredness, and the role of the teacher as a facilitator and counselor. This would help the researcher reflect on the new method and modify it for effective teaching in the future lessons. More specifically, the main objectives set for this AR were:

i. To find out the effectiveness of TBL as an approach for teaching paragraph level writing.

ii. To facilitate students write a short paragraph by working in groups and sharing ideas and language skills.

\section{METHOD}

The researcher decided to use personal notes, peer observation report, student survey questionnaire, and samples of students' writing as data collection instruments.

\section{Teacher Observation}

Teacher observation included teacher's notes of students' reaction to the task as well as their interaction while working through different stages of the task. Moreover, teacher's understanding of a certain situation during the task performance and any language need of the students that might arise also formed part of this data collection instrument. Lastly, teacher's reflection on his role as a classroom facilitator in the management of all the planned stages of the task was also recorded to be collated with other data.

\section{Peer Observation}

The researcher requested a colleague to observe this lesson. The peer observer with an MA in English and Cambridge ESOL Celta had taught in the EFL contexts for more than 15 years. With sufficient experience of conducting peer observations, he was assumed to produce a reliable report on the lesson. To this end, a peer observation form (Table 2) from Cambridge Awards cited in Ahmad (2020) was adapted and shared with the observer to help him take important notes of the happenings in the class. The presence of the observer was expected to provide an objective appraisal of the teacher's performance and assessment of the students' response to the task. 
TABLE 2:

PEER OBSERVATION FORM

\begin{tabular}{|c|c|c|c|}
\hline & $\begin{array}{l}\text { Observation } \\
\text { Descriptors } \\
\end{array}$ & $\begin{array}{l}\text { Observation Benchmarks } \\
\text { The teacher; }\end{array}$ & $1 / 2 / 3$ \\
\hline \multirow[t]{2}{*}{1} & $\begin{array}{l}\text { Lesson Profile: Choice } \\
\text { of the Topic }\end{array}$ & Identifies a specific area appropriate to learning context \& learners' needs & \\
\hline & Observer's Comments & & \\
\hline \multirow[t]{10}{*}{2} & Planning \& $\quad \&$ & Provides learner profile & \\
\hline & Preparation & States lesson aims & \\
\hline & & Includes language analysis (communicative features of discourse) & \\
\hline & & Establishes link with previous learning & \\
\hline & & Mentions assumptions about learners' knowledge etc. & \\
\hline & & Shows familiarity with learners' problems \& solutions & \\
\hline & & Sequences procedures \& activities to achieve lesson aims & \\
\hline & & Develops \& keeps effective materials & \\
\hline & & Manages time through lesson stages effectively & \\
\hline & Observer's Comments & & \\
\hline \multirow[t]{16}{*}{3} & Lesson Delivery & Teaches as planned appropriate to the learners needs and level & \\
\hline & & Allows equal participation & \\
\hline & & Is receptive \& responds to learners' participation & \\
\hline & & Uses procedures, activities \& techniques to achieve lesson aims & \\
\hline & & Exploits materials to support learning to achieve aims & \\
\hline & & Delivers a coherent \& suitably varied lesson & \\
\hline & & Monitors \& checks students' learning \& responds as appropriate & \\
\hline & & Uses language appropriate to the teaching context & \\
\hline & & Provides appropriate models of language use & \\
\hline & & Provides accurate information about language use & \\
\hline & & Notices learners' output \& incorporates it into the learning process & \\
\hline & & Implements LP \& adapts it to the emerging needs & \\
\hline & & Manages the classroom space, furniture \& other equipment effectively & \\
\hline & & Sets up whole class/pair/group work as appropriate & \\
\hline & & Ensures the learners stay focused on lesson aims \& the learning outcomes & \\
\hline & Observer's Comments & & \\
\hline
\end{tabular}

\section{Students' Profile and Survey}

A students' survey questionnaire (Table 3) was generated to help gauge their perceptions about the task, their problems, and their level of motivation. The target group of learners were 20 male Arabic speaking Preparatory Year students in an age range of 18 to 22 at the University of Jeddah, Saudi Arabia. Most of the students had problems using English language for communicative functions and were, therefore, reluctant to participate actively in the classroom activities. However, if motivated, they would set to work but resorted to the teacher input quite frequently. With an assumed elementary level of English language proficiency, they attended a 14 week term based on an integrated course design. The four language skills of listening, speaking, reading and writing were taught through a preset textbook. Owing to the institutional and curricular constraints, there was no separate provision for specialized instruction for the writing skill which, consistent with many a research findings (e.g. Ahmad, 2017) in the Saudi EFL context, these learners found challenging and to some extent intimidating. Most of the time, PPP was employed as a teaching approach. Customized materials to facilitate and reinforce the learning outcomes were also sometimes used. Writing as a language and literacy skill was assessed summatively on a five-point criteria through a writing task which required the students to produce either a narrative or a descriptive or an opinion paragraph of no less than 150 words.

TABLE 3:

STUDENTS' SURVEY

\begin{tabular}{|c|c|c|c|}
\hline & Survey Statements & YES & NO \\
\hline 1 & The task was interesting & & \\
\hline 2 & I enjoyed working in my group & & \\
\hline 3 & Teacher's instructions were easy and clear & & \\
\hline 4 & The teacher helped me/my group with my/our problems & & \\
\hline 5 & This way of writing a paragraph is easy & & \\
\hline 6 & I learnt new words & & \\
\hline 7 & I learnt how to organize ideas & & \\
\hline 8 & I made suggestions to my group & & \\
\hline 9 & I did some correction work & & \\
\hline 10 & I finished my task on time & & \\
\hline 11 & I will like to do these types of tasks again & & \\
\hline
\end{tabular}

\section{Samples of Students' Writing}

Samples of the paragraph written by the students during the lesson were collected and analyzed to identify their strengths and weaknesses in terms of fluency and accuracy. The students' writing samples were analyzed according to their response to the rubrics for the three worksheets (Appendix 2). These samples also helped in collection of data on students' needs and were collated with teacher and peer observation results. 


\section{Lesson Procedure}

The learners worked in groups to first brainstorm and list five points about "Problems of living in a foreign country". Since the author was using TBL as a teaching approach, he did not propose to pre-teach key vocabulary and language forms. The students spoke to each other to activate their existing vocabulary and language forms for the task in hand. First, they listed five points on the topic. Then, they used their language knowledge to make a short oral presentation before the class. Next, they wrote a topic sentence for the proposed topic - a skill they had already learnt and practiced on this course - and organized their points to write a short paragraph. They were provided with a list of the signal words which they had to use for the organization of the paragraph. Teaching through TBL approach was expected to highlight some of the language needs of the learners which were dealt with during the peer correction and the feedback stage. Finally, the students wrote the edited paragraphs on a new worksheet which was designed to reinforce the newly learnt language forms and skills.

\section{Assumed Knowledge}

It was assumed that the learners were familiar with a number of items both from the language systems and the skills areas which they might need to employ during the present task. They had already been exposed to chronological order and the related signal words as well as how to write topic sentence and supporting detail. Besides, they had also done some classroom practice in writing simple and compound sentences. They were also familiar with using present simple, past simple and future simple tenses. Now, they were set to produce a paragraph organization by order of importance. The author felt that with the background knowledge that they had, they could be helped to write paragraphs using "order of importance".

\section{Anticipated Problems and Appropriate Solutions}

Since the learners were doing a task without the usual context development and presentation from the teacher, it was anticipated that they might face certain problems. First, they might not properly understand the task and the stages involved in it. The teacher would try to present the instructions clearly and loudly so that everybody understood. If someone still was not clear about what to do, he could ask his group member for clarity. Secondly, as the students were elementary level learners, they might find it difficult to choose the appropriate vocabulary. The teacher decided to use scaffolding as a strategy to deal with this issue. It was also anticipated that some learners might have a slow writing speed. It was decided to involve the learners in group work so that they could get some support from their peers. Besides, time management could be a problem in task realization. So, the teacher had to be vigilant to ensure that each task stage finished on time. Those students were asked to present and write who were fast in their groups. Similarly, in the language focus and peer correction stage, the groups were asked to stick their paragraphs on the board and suggest correction to save time.

\section{RESULTS}

The post lesson observations were based on the notes taken by the author and the peer observer, and results obtained through the student survey questionnaire and the writing samples of the students. The author was able to develop the schemata of the students by asking them a few questions on the topic. There were 20 students distributed into five groups of four students in each. As observed by the peer observer and the students, the instructions were fairly clear. The students had no problems in starting and progressing with the task. It was found that most of the lesson objectives were successfully achieved.

\section{Teacher Evaluation}

As revealed in the task worksheets, the students were able to complete the task through collaborative learning. They could brainstorm five points about the topic and then present their ideas orally. Next, they worked with each other to first write the topic sentence and then, organize their points as supporting sentences using the signal words. One group used the past tense and narrated an experience. But the most serious issue was the spelling. All the paragraphs written had spelling problems. However, the students showed good understanding of the use of signal words and organized their ideas well. TBL proved to be an effective teaching approach as students collaborated with each other towards task realization with minimal stress that was NOT a typical feature of other tasks such as done in a PPP approach. 4 out of 5 groups expressed their willingness to do these types of tasks again. Moreover, all the lesson stages were well managed except for the last one where the students had to practice new words and spelling, rewrite the correct paragraph and save it for their portfolios. The students showed a higher level of motivation as compared with the previous lessons which were mostly based on PPP framework. The students were also keenly interested in the task and according to the peer observer's findings they were 'eager to participate'. Because of the students' active participation, the author's role was reduced to that of a facilitator and counselor. It was fun to see students working together and consulting the author only when needed and that too only for advice or clarity. There was more student talk time (STT) and less teacher talk time (TTT), and according to the observer TTT was approximately $30 \%$ of the lesson.

However, the language focus stage was not as effective as the author had planned. It turned out to be more teachercentered rather than student-centered. This was something that the author needed to control. Similarly, the students' peer correction was not well managed. The author could have given them more time to reflect on each other's writing and suggest correction. Finally, the time left for the final stage was a little short and the author had to wind up things in haste which probably lead to more TTT and also affected peer correction and practice. 


\section{Peer Observer Report}

The subsections below report peer observer's comments on the lesson as elicited from the lesson observation criteria (Table 2).

\section{Lesson Profile}

The teacher demonstrated a good understanding of the theory and a sensible choice for his own development and the needs of his learners. He showed a lot of insight into their likely reactions and took a sensible stand on reflection. However, more specific objectives and more on how he understood what he did from the data would be good. He presented a wide-ranging discussion of the various strands of belief about second language acquisition that underlie a task based approach to teaching. It was good to see that he could relate theory to practice. Some areas could do with further exemplification, but on the whole the lesson profile was well stated. The teacher made a sensible case for his choice of focus, grounding it in his own overall development and tendencies that had arisen so far in the professional development context. It was a rational choice to try and move to a more learner-centered environment. The teacher was particularly clear about some of the likely efficiency of his options for gathering data - the section on why he took the approach and what he proposed to do with feedback from the learners was a strength.

The teacher had set up objectives to evaluate the AR lesson. This section of the lesson profile was somewhat less robust. While he set out a sensible number of objectives they could be more tightly written. It was good that he also realized that he needed to collect data in order to assess the effectiveness of what he did in addressing the objectives, and good to triangulate by asking himself, the learners and an impartial observer, but here too, while the intention was clear, more detail would be appropriate. The reader should be able to see questions and feedback and the teacher should be able to pinpoint what had led him to his conclusions.

\section{The Lesson Plan}

The procedure was fairly clear with a clear context, some variety and opportunities for different interactions. Overall, there was a logical shape to the lesson; however, some further communicative practice or use of the target language would also have been useful. The procedures pages were generally well-presented and organized. Bullet points helped to break down the steps of most stages clearly, and interaction patterns were clearly shown. Stage aims were learnerfocused as well as timings were clearly indicated. However, some procedures needed to be more clearly explained to show what the learners would do and how. It would also help if the teacher had labeled handouts - HO1, HO2, etc. to show what will be used when. Some timings seemed a little unbalanced in the later stages of the lesson, especially the language stage, which was quite long.

\section{Lesson Delivery}

The teacher had a very strong, positive classroom presence and encouraged the learners well. There was a clear context for this lesson and generally good use of visuals. The teacher had some good techniques in place - eliciting and discreet monitoring and drilling - and made excellent use of the board to support his instructions. There was also some variety in task and interaction, including some movement. The learners generally seemed to grasp the task, but the teacher should work on his own language -to grade his language to the learners' level better and try to elicit as much as possible rather than just spoon-feeding language.

The teacher had a relaxed, confident and friendly manner and did well to encourage equal participation through good nominating using appropriate gestures. The learners were generally well-engaged, he varied his role at times and there were opportunities for different interactions. He listened to the learners and responded naturally. His own language was mostly accurate and at times appropriately graded. The delivery was clear and at a natural speed. The practice activities helped to engage the learners in their respective groups and stay focused on the task. It was good to see him encouraging the learners to self or peer-correct. The basic sequence of the lesson was good and there was a clear context set and maintained. As mentioned, the teacher had some good techniques in place - eliciting and supportive monitoring. Engaging students with listing ideas on the topic and then asking them to make an oral presentation was a good idea for maintaining context, and the supported his plan with some different work sheets to help the learners think about the task in different ways. All of these made the lesson coherent and added variety in task and interaction. The teacher monitoring was discreet but supportive and feedback was given on all tasks. He implemented his lesson mostly as planned, making a time-related decision not to include one activity. Great to see him using the board so well in giving instructions. This really helped as a demo and the check understanding. Instructions were also well-staged. Overall, the learners were focused and the lesson aims were achieved. However, the learners could have been better engaged if the teacher aimed to elicit more and involve them more in the learning process.

\section{Analysis of Students' Writing}

Five groups (A to E) participated in the task and their writing was analyzed on the basis of the groups' compliance with the instructions of the tasks in Worksheet 1, 2 and 3 (Appendix 2). Task in Worksheet 1 required the groups to list five points about the topic. All the groups completed the task successfully; however, four groups only wrote one-word idea. Task in Worksheet 2 was to produce the first draft of the paragraph including a topic sentence and supporting detail based on the five ideas completed in Worksheet 1. The groups had also to use transition words from the list provided to them. This was followed by peer correction of the paragraph. All the groups could complete the task with minor deviations from the rubrics. For instance, Group A, B and E did not mark the errors during the peer correction stage. Group B could not produce the topic sentence for their paragraph. Except for Group B, all other groups followed 
the same order in organizing the supporting detail as had been elicited in Worksheet 1. Transition words were used accurately by all the groups; however, Group A and E missed one or two points in the supporting detail. Worksheet 3 was the revised or the final draft of the writing task. Group A retained the first draft and did some minor edits. For instance, the general mention of the "country" was specified as "USA" in the final draft. But the group overlooked spelling and other issues of grammar and mechanics. Group B retained the first draft with some edits to the issues of mechanics. They did not pay heed to spelling and other issues. Group C did some editing by changing the word "living" to "live" and "to living" to "to live". Group D also did some editing by substituting the word "hard" by "difficult"; however, this led to inaccuracy in meaning. Group E rephrased a sentence to begin with "when". They also changed the phrase "other country's food" to "other types of food". Group G did some error correction to replace "communication" with "communicate". However, they did one error while doing correction on the first draft - instead of using "homesickness" as they had in the first draft, they used "homesick".

\section{Students' Survey}

The result obtained from the students' survey which was based on 11 items (Table 3) was mostly answered in the affirmative. One group felt that they could not learn how to organize ideas. Group A believed that this way of doing writing was not easy and that they could not make suggestions as group members. Most of the disagreement was expressed by Group B who found the task uninteresting and challenging. They felt that they needed more time to finish the task and that they would not like to engage in such tasks in future lessons.

\section{DISCUSSION}

The students are monolingual Arabs with almost the same cultural background. They are either absolute beginners or false beginners when they start learning English here, and by the time they pass first semester of the Preparatory Year, it is assumed that they have achieved the elementary level of English language proficiency. One of the formidable challenges of language instruction to these students is the fear that English is a difficult language in terms of the rules and the functions which are taught explicitly. TBL can help remove this fear by providing the students an opportunity to work in pairs or groups and do a task which they can relate with the real life situations. Consistent with Wang's (2019) findings, it can be assumed that since TBL focuses on fluency, meaning, and task realization, linguistic inhibitions of the students can be easily overcome as they feel relaxed about the forms of the language. They can also employ their background knowledge of the world and the language to complete the task. In addition, TBL allows the students to use their first language (L1) during group discussion and this removes not only a serious barrier to language learning but also provides an opportunity of participation to weaker students. Moreover, TBL helps manage class size effectively. The researcher could use it for a class of 20 students. Group work which can be extended to a larger class promotes a higher level of motivation since the students work in collaboration sharing their ideas and language competence. The teacher, as facilitator, is be able to identify the language needs of the students that may arise during the course of the lesson and has a clear focus to exploit during the feedback session. Most importantly, the language focus stage of the lesson also allows discussion of the language forms which have been used in the task. Hence, the students get sufficient practice and exposure to both fluency and accuracy involved in the task. Successful completion of the task gives students a real sense of achievement, and thereby a higher level of motivation for the next and future tasks.

However, as with other teaching approaches, TBL cannot be applied in a fixed template format, especially in an AR initiative as of the present study. It takes time to break what may be called pedagogic routines which are stereotyped procedures adopted by teachers while performing a typical teaching component repetitively or continually over a considerable period of time. The students also anticipate typical techniques or strategies from the teachers and consequently develop a fixed way of responding to such type of tasks. That is why when a teacher experiments with a novel approach, there are chances that he may not find it as effective as the other approach he has been using for a long time. Challenges in regard to activity management, task achievement, and feedback procedures and quality may come to the fore. Similarly, the students may find the new way of teaching boring or challenging because of its clash with the pedagogic routines. It is here that the role of reflective practice and AR activates. Following Wallace (1991), teachers can look back to their classroom practice to improve their future teaching. A reflective teacher can take note of the issues through the course of the lesson and assign them to either lesson planning, or lesson delivery, or feedback, or classroom management, or the instructional materials. These reflective notes help in the future planning and are expected to bring improvements to the overall teaching and learning experiences.

\section{Limitations and Suggestions: Post Teaching Action Plan}

The study is not without its limitations as it is based on one lesson report only and as such has limited generalizability. However, the study can motivate further teaching initiatives that can be incorporated in future AR projects. For instance, TBL can be extended to other teaching foci such as helping students with developing their speaking and reading skills or with new grammar, lexis and discourse features. An important area of investigation would be to target feedback and error correction strategies especially by asking a colleague for peer observation or by video-recording the lesson or a series of lessons. Teaching approaches like the Silent Way, and Community Language Learning can also be made part 
of the AR endeavours which can not only expose teachers to new pedagogic practices but also motivate learners (Fu, 2014) to learn from a variety of teaching styles.

\section{CONCLUSION}

Reflective practice and action research are at the heart of EFL pedagogy both implicitly and explicitly. Teachers are themselves observers of their classroom practice which if formalized can generate valuable data on a variety of teaching and learning dimensions. This data can be later utilized for improving the quality of teaching and achieving a higher level of learning outcomes. If institutionalized and made a collaborative activity involving EFL teachers at the departmental level, the data obtained from classroom observations can also be effectively used for professional development of the faculty and other macro projects such as the syllabus design and materials development. More importantly, such an attitude to professional development whereby teachers try new teaching methods such as the TBL encourages both teacher and learner autonomy with the result that the teachers assume responsibility for the quality their teaching practice and the students of their learning achievement.

\section{ApPENDIX 1. TBL LeSSON Plan/ProcedurE}

\begin{tabular}{|c|c|c|c|c|}
\hline Time & Stage/Stage $\operatorname{Aim}(s)$ & Procedure & Interaction & Materials \\
\hline $\begin{array}{l}7 \mathrm{~min} \\
09: 15-09: \\
22\end{array}$ & $\begin{array}{l}\text { Pre-task: (Lead-in) } \\
\text { - to form SS groups } \\
\text { - to develop the schemata by } \\
\text { elicitation } \\
\text { - to introduce the topic. }\end{array}$ & $\begin{array}{l}\text { 1. Greet the learners. } \\
\text { 2. Ask SS if they have ever traveled abroad, when } \\
\text { did they visit, what did they see, how did they } \\
\text { feel? etc } \\
\text { 3. Form } 3 / 4 \text { groups } \\
\text { 4. Tell SS that they will: } \\
\text { Work in groups } \\
\text { List five points about problems of living in a } \\
\text { foreign country. } \\
\text { Make a short oral presentation } \\
\text { Organize these points to write a paragraph using } \\
\text { signal words. } \\
\text { Do peer correction } \\
\text { 5. Give SS worksheet } 1 \text { (Appendix 2) }\end{array}$ & $\mathrm{T} \leftrightarrow \mathrm{SS}$ & $\begin{array}{l}\text { White board } \\
\text { Handout/Worksheet }\end{array}$ \\
\hline $\begin{array}{l}25 \text { min } \\
09: 22- \\
09: 47\end{array}$ & $\begin{array}{l}\text { The Task Cycle: } \\
\text { - to let SS complete the first } \\
\text { part of the task } \\
\text { - to allow SS work in } \\
\text { collaboration } \\
\text { - to identify SS language } \\
\text { needs }\end{array}$ & $\begin{array}{l}\text { SS consult one another and list five points } \\
\text { The groups make their presentation before the } \\
\text { class } \\
\text { Give SS worksheet } 2 \text { (Appendix 2) } \\
\text { Ask SS to write the Topic Sentence } \\
\text { Ask SS to use their } 5 \text { points and signal words to } \\
\text { write a short paragraph } \\
\text { Monitor and observe the SS working in groups }\end{array}$ & $\begin{array}{l}\mathrm{T} \leftrightarrow \mathrm{SS} \\
\mathrm{SS} \leftrightarrow \mathrm{SS} \\
\mathrm{T} \leftrightarrow \mathrm{SS}\end{array}$ & $\begin{array}{l}\text { White board } \\
\text { Hand-out/worksheet }\end{array}$ \\
\hline $\begin{array}{l}18 \mathrm{~min} \\
09: 47- \\
10: 05\end{array}$ & $\begin{array}{l}\text { The Language Focus } \\
\text { - To help SS do peer } \\
\text { correction } \\
\text { - To facilitate learning by } \\
\text { teacher correction/feedback } \\
\text { - To help learners practice } \\
\text { - To get learners' feedback on } \\
\text { the lesson }\end{array}$ & $\begin{array}{l}\text { Ask SS to stick the paragraphs on the whiteboard } \\
\text { The SS read the paragraphs } \\
\text { Ask SS to suggest correction/improvement in } \\
\text { paragraph 1. } \\
\text { Tell SS to focus on verb forms, nouns, signal } \\
\text { words, spelling, capital letters, and the full stop. } \\
\text { The groups will correct their paragraphs } \\
\text { Give SS your feedback on their work especially } \\
\text { to any language need that has arisen during the } \\
\text { lesson or the peer correction stage. } \\
\text { Ask SS to write the corrected paragraph on } \\
\text { worksheet } 3 \text { (Appendix 2) } \\
\text { Ask SS to save the new paragraph in their } \\
\text { portfolios. } \\
\text { Give SS survey questionnaire (Table 3) to } \\
\text { complete } \\
\text { Thank and praise the learners }\end{array}$ & $\begin{array}{l}\mathrm{T} \leftrightarrow \mathrm{SS} \\
\mathrm{S} \leftrightarrow \mathrm{S}() \\
\mathrm{T} \leftrightarrow \mathrm{SS} \\
\text { cards }\end{array}$ & $\begin{array}{l}\text { Hand-out/worksheet } \\
\text { White board }\end{array}$ \\
\hline
\end{tabular}

\section{APPENDIX 2}

\section{Worksheet 1}

Name:

Group:

Discuss the topic "Difficult Things about Living in a Foreign Country" in your group and list five points on the space given below for this.

Point 1:

\section{Point 2:}


Point 3:

Point 4:

Point 5:

\section{Worksheet 2}

Name:

Use the five points from worksheet 1 as supporting sentences to write a short paragraph on "Difficult Things about Living in a Foreign Country". Begin your paragraph with the topic sentence. You can use the signal words in the box given below to organize your ideas.

first, first of all, secondly, also, in addition, moreover, most importantly, finally

Difficult Things about Living in a Foreign Country

Worksheet 3

Name:

Group:

Rewrite the corrected paragraph on the space provided below and save the draft in your portfolio.

Difficult Things about Living in a Foreign Country

Adapted from: Blanchard, K. \& Root, C. (2010), Ready to Write 2: Perfecting Paragraphs, New York: PearsonLongman.

\section{REFERENCES}

[1] Ahmad, Z. (2017). Empowering EFL learners through a needs-based academic writing course design. International Journal of English Language Teaching, 5(9), 59-82.

[2] Ahmad, Z. (2020). Peer Observation as a Professional Development Intervention in EFL Pedagogy: A Case of a Reading Lesson on Developing the Top-down Processing Skills of the Preparatory Year Students, International Linguistics Research, 3(1), 1-15. doi: https://doi.org/10.30560/ilr.v3n1p1.

[3] Banegas, D. L. (2018). Towards understanding efl teachers' conceptions of research: Findings from Argentina. Profile: Issues in Teachers' Professional Development, 20(1), 57-72. doi: https://doi.org/10.15446/profile.v20n1.61881. 
[4] Banegas, D., Pavese, A., Velázquez, A., \& Vélez, S. M. (2013). Teacher professional development through collaborative action research: Impact on foreign English-language teaching and learning. Educational Action Research, 21(2), 185-201. https://doi.org/10.1080/09650792.2013.789717.

[5] Blanchard, K. and Root, C. (2010). Ready to write 2: perfecting paragraphs, New York: Pearson-Longman.

[6] Borg, S. (2006). Conditions for teacher research. English Teaching Forum, 44(4), 22-27.

[7] Burns, A., \& Westmacott, A. (2018). Teacher to researcher: Reflections on a new action research program for university EFL teachers. Profile: Issues in Teachers' Professional Development, 20(1), 15-23. https://doi.org/10.15446/profile.v20n1.66236.

[8] Burns, A. (2014). Professional learning in Australian elicos: An action research orientation. English Australia Journal, 29(2), 3-20.

[9] Cohen, L., \& Manion, L. (1985). Research methods in education. London: Croom Helm.

[10] Curran, P. and Dusap, A. (2000), Methodology in language learning T-KIT 2, Strasbourg, Cedex: Council of Europe \& European Commission.

[11] Frost, R. (2004). A Task-based approach, Turkey: British Council, retrieved on 9th January, 2020 from http://www.teachingenglish.org.uk/articles/a-task-based-approach.

[12] Fu, X. (2014). An Action Research Report on Promoting Learners "'Motivation in College English Intensive Reading Course in China, Theory and Practice in Language Studies, 4(4), 715-724. doi:10.4304/tpls.4.4.715-724.

[13] Harmer, J. (2001). The practice of English language teaching. London: Pearson Education Limited.

[14] Krashen, S. and Terrell, T. (1983). The Natural Approach, Oxford: Pergamon Press.

[15] Mc Niff, J. and Whitehead, J. (2002). Action Research in Higher Education. Brisbane, Australia: The Centre for Advancement of Learning and Teaching.

[16] Negi, J.S. (2016). Improving Teaching through Action Research; Perceptions, Practices and Problems (3Ps): Voices from Secondary Level Teachers in an EFL Context. ELT Voices, 6 (4), 18-30.

[17] Norton, L. (2001). Researching Your Teaching: The Case for Action Research, Psychology Learning and Teaching, 1(1), 21-27

[18] Nunan, D. (1989). Designing tasks for the communicative classroom. Cambridge: Cambridge University Press.

[19] Nunan, D. (2004), Task-based language teaching, Cambridge: Cambridge University Press.

[20] Prabhu, N.S. (1987). Second Language Pedagogy. Oxford: Oxford University Press.

[21] Richards, J. C. (1990). The dilemma of teacher education in second language teaching. In J. C. Richards \& D. Nunan (Eds.), Second language teacher education (pp. 3-15). Cambridge: Cambridge University Press.

[22] Richards, J.C., \& Lockhart, C. (1996). Reflective teaching in second language classrooms. New York, NY: Cambridge University Press.

[23] Richards, J. C. \& Renandya, W.A. (2002). Methodology in language teaching. Cambridge: Cambridge University Press

[24] Schön, D. A. (1983). The reflective practitioner: How professionals think in action. New York: Basic Books.

[25] Smith, R., Connelly, T., \& Rebolledo, P. (2014). Teacher-research as continuing professional development: A project with Chilean secondary school teachers. In D. Hayes (Ed.), Innovations in the continuing professional development of English language teachers (pp.111-128). London, UK: British Council.

[26] Troudi, S. \& Riley, S. (1996). Action research: Using your classroom for professional development. Paper presented at the 30th Annual meeting of the Teachers of English to Speakers of Other Languages. Chicago, March 1996.

[27] Wallace, J. M. (1991). Training language teachers. Cambridge University Press: Cambridge.

[28] Wang, S. (2019). The Application of Task-based Approach in English Grammar Teaching in Junior High Schools, Journal of Language Teaching and Research, 10(2), 304-310, DOI: http://dx.doi.org/10.17507/jltr.1002.12.

[29] Willis, J. (1996). A framework for task-based learning, Harlow: Longman.

[30] Willis, D. and Willis, J. (2001), Task-based language learning. In Carter, R. and Nunan, D. (eds) The Cambridge guide to teaching English to speakers of other languages, Cambridge: Cambridge University

Zulfiqar Ahmad has a PhD in Applied Linguistics from De Montfort University, UK. He also holds MA in TESL, MA in English, and Cambridge ESOL Delta. With over 25 years of ELT experience in Pakistan and abroad, he is presently an EFL Instructor at the University of Jeddah, Saudi Arabia. His main research interests include academic writing, academic literacies, discourse and genre analysis, language assessment/testing, and TESOL. 